Research, part of a Special Feature on Systems Science for Managing Europe's Seas

\title{
Temporal constraints on ecosystem management: definitions and examples from Europe's regional seas
}

$\underline{\text { Tim O'Higgins }}^{1}, \underline{\text { Philip Cooper }}^{2}, \underline{\text { Eva Roth }}^{3}, \underline{\text { Alice Newton }}^{4}, \underline{\text { Andrew Farmer }}^{5}, \underline{\text { Ian C. Goulding }}^{6}$ and $^{\text {Paul Tett }}{ }^{1}$

ABSTRACT. Our ability to meet environmental targets is often constrained by processes and events that occur over long timescales and which may not be considered during the planning process. We illustrate with examples and define three major types of temporal scale phenomena of relevance to marine managers: Memory and Future Effects (jointly called Legacy Effects) and Committed Behaviors. We examine the role of these effects in achieving marine environmental targets in Europe under the Marine Strategy Framework Directive and the implications for future management, indicating the increased importance that these temporal phenomena give to reducing future pressures.

Key Words: adaptive management; ecosystem approach; Marine Strategy Framework Directive; temporal scales

\section{BACKGROUND}

The ecosystem approach to management is receiving increasing international attention as an integrated structure for decisionmaking that supports the setting of environmental goals for using and maintaining ecosystem services and the design of management measures to achieve these goals (e.g., CSIRO 2003, Millennium Ecosystem Assessment 2003, EPA 2009). Implicit in this approach is the recognition of the constraints on management imposed by the complex characteristics of social-ecological systems, meaning that targets for environmental quality should be attainable (i.e., realistic) and adaptable as constraints change (Borja et al. 2012). Among these constraints are those arising from the temporal characteristics of social-ecological systems. The effects of past actions may be embedded in these systems such that the achievement of future targets and goals is not simply a product of future actions. We propose a functional classification of such embedded effects as a contribution to the development of assessment methodologies so that they more explicitly recognize inherent constraints from past actions.

While the proposed classification and its definitions are expressed in general terms, to make its concepts more concrete, we ground our discussion in the context of marine ecosystems and the European Marine Strategy Framework Directive (MSFD) (European Commission 2008). This Directive adopts the ecosystem approach and requires affected countries to achieve or maintain Good Environmental Status (GEnS) in the marine environment, as expressed through 11 descriptors (D1-D11) prescribed in the Directive (European Commission 2008) and subsequently refined (European Commission 2010). The MSFD sets out a strict timetable for initial assessment (of both the state of ecological systems and the effects of human activities on them), agreement of specific targets for the descriptors, implementation of a program of measures, and finally, achievement of GEnS (European Commission 2008, Borja et al. 2010a, O'Higgins and Roth 2011, Borja et al. 2012). Implementation of the Directive will be an iterative process with an adaptive management cycle for target setting and achievement every six years, following the initial cycle, which ends in 2020 . This represents a major challenge for European marine managers (Borja 2006, Mee et al. 2008, Cardoso et al. 2010, Potts et al. 2012).
We employ the definitions of the Driver Pressure State Welfare Response (DPSWR) conceptual framework (Cooper 2013), a modified form of the Driver Pressure State Impact Response framework widely used in the field of marine environmental management (e.g., Elliott 2002, Atkins et al. 2011). DPSWR emphasizes the significance of specifying Driver activities and distinguishes impacts on the environment from those on humans (i.e., Welfare effects). Thus, DPSWR isolates categories dealing with the benefits (Driver activities) and costs (Welfare effects) associated with environmental State change, consistent with the notion of cost-benefit analysis. We introduce a temporal dimension to the framework to highlight the relevance of the past to environmental management. Within the terms of this framework, Responses designed to achieve future goals and targets for environmental State need to recognize the temporal characteristics of the Drivers, Pressures, and environmental State changes relevant to a particular objective. Effective Responses must consider the ecological properties inherent in specific socialecological systems and may seek to sever or reduce the link between Pressures and Drivers or reduce the levels of Drivers and Pressures in the future. However, future environmental State may depend not just on societal Response measures and future actions but also on historical and current Drivers, Pressures, and environmental State.

At its simplest, a past release of a marine pollutant could affect our ability to achieve GEnS today or in the future if the pollutant is persistent. In such a case, historical Driver, Pressure, and State alter current and potential future environmental status. The residence time of the particular pollutant in a particular system is dependent on ecological properties of the system. Its physical, chemical, and biological characteristics combine to impose constraints on the rates of ecosystem processes and of progress towards management goals. These complex combinations of properties are unique to each sea and vary between systems. For example, the flushing times of Europe's seas (Baltic, Black, North, and Mediterranean) range over three orders of magnitude from approximately annual in the North Sea (Rodhe et al. 2006) to millennial in the Black Sea (Murray et al. 1991). Though the physical properties determining flushing times are relatively simple and reasonably well understood, recovery times of ecosystems vary (Borja et al. 2010b). Nonlinearities in system

${ }^{1}$ Scottish Association for Marine Science, ${ }^{2}$ School of Management, University of Bath, ${ }^{3}$ Southern Denmark University, ${ }^{4}$ Norwegian Institute for Air Research (NILU), ${ }^{5}$ Institute for European Environmental Policy, ${ }^{6}$ Megapesca Lda. 
response to changes in environmental pressures are the rule rather than the exception, and include shifting baselines (Duarte et al. 2009) as well as regime shifts to new stable states, which may be the result of either anthropogenic or natural pressures (Folke et al. 2004, De Young et al. 2008, Andersen et al. 2009).

We identify, formally characterize, and provide illustrations and rigorous definitions of constraints resulting from Driver activities that are not amenable to Response in the short to medium term. We apply these concepts in the analysis of cases studied from each of Europe's regional seas (see Mee et al. 2015, for details) and discuss the implications for policy and management. We conclude with comments on the operationalization of these concepts and highlight their policy relevance.

\section{DEFINITIONS, CLASSIC ILLUSTRATIONS, AND CONCEPTUAL FRAMEWORK}

Over the period from the present to 2020, the target date for achievement of GEnS, the State of marine ecosystems will not simply represent the effect of Drivers and Pressures arising in that period but will also be affected by the legacy of previous activities. In addition, Drivers may be so deeply rooted in human systems that realistically they cannot be materially changed in an intended direction during that period. To formalize and develop these ideas, we define temporal constraints on policy or management Response over a prospective (planning) period as system properties or conditions that are not susceptible to Response measures in that period. Thus, constraints constitute part of the context within which decisions for a planning period have to be formulated.

Effective management must focus on the elements of a socialecological system that are amenable to change through human action. Elements of the system, including irreversible changes, that cannot be altered through management measures may be considered exogenous. They lie outside the part of the system under the sphere of influence of the manager (Elliott 2011). The most obvious and widespread example of an exogenous constraint is the inherent variability in natural systems, which introduces an influence on the interactions between human and ecological systems. Natural cyclical forcing of the environment occurs on many timescales. On the millennial timescales (of human evolution and emergence of civilization), climate is controlled by planetary oscillations, Milankovitch cycles (Milankovitch 1941). In the short to medium term (annual to decadal timescales), there are many cyclical phenomena forcing environmental processes. A prominent European example is the Atlantic Multidecadal Oscillation (Schlesinger and Ramankutty 1994). It results in naturally changing conditions of the North Atlantic and the North Sea, which are observed throughout the entire ecosystem from phytoplankton to marine mammals (Nye et al. 2014). These cycles comprise natural variability, forming a baseline for environmental management. This variability should be considered when setting targets but is not manageable through policies or measures.

Our focus is on endogenous constraints, those that derive from human systems through Driver activities. Using a soft-systems methodology approach (Checkland and Poulter 2006), over a two-day period, an expert working group focused on regional and subregional case studies for each of Europe's regional seas to define and classify the temporal constraints on management (see
Mee et al. 2015) for methodological details. While many papers have dealt with the legacy of historical environmental damage (e.g., Connor et al. 2007, Stein and Cadien 2009, Apeti et al. 2010, Rainbow et al. 2011), we present a systematic classification of temporal effects for application in environmental decisionmaking. We distinguish two broad types of such constraint according to when the relevant Driver activities arise in relation to the planning period: Legacy Effects and Committed Behaviors. We further divide Legacy Effects between Memory Effects and Future Effects, depending on which ecosystem compartment has been affected prior to the planning period.

The definitions of the different types of Legacy Effects (Memory and Future) and Committed Behaviors are summarized formally in Fig. 1a using a simple notation to indicate the critical DPSWR components and timings. Fig. $1 \mathrm{~b}$ provides a conceptual model that presents these effects in a broader context.

\section{Memory Effects}

Legacy Effects arise from past Driver activities (i.e., prior to the planning period) that have altered ecosystems in such a way that they may be instrumental in further state change in marine systems during the planning period. Where the legacy is reflected in the state of marine systems at the start of the planning period, we refer to this as a Memory Effect. In such cases, a "memory" of previous marine system change is carried into the planning period and leads to further State change, either naturally (subject to exogenous forcing) or as a result of Pressures arising in the planning period.

A striking European example of a Memory Effect is that of persistent eutrophication in the Baltic Sea. Large loads of nutrients primarily from agricultural and waste water inputs led to a severe eutrophication problem in the 1970s and 1980s. The symptoms included increased phytoplankton primary production and increased sedimentation of organic matter on the seabed. While the total nitrogen and phosphorus inputs to the Baltic since the mid-1990s have been successfully curtailed, the total phosphorus concentrations have not decreased (ICES 2010). This is due to the permanent stratification of the Baltic Sea and limited physical flushing of the system through exchange with the North Sea. The phosphorus concentrations remain high because internal loads of iron-bound phosphorus are released from sediments under low oxygen conditions, which fuels continued eutrophication (Munkes 2005) and determines the effects of future management efforts (Österblom et al. 2010).

\section{Future Effects}

Where the legacy of previous Driver activity is carried forward from a nonmarine ecosystem, we refer to a Future Effect. Such an effect arises where the nonmarine State change exerts Pressure on marine systems during the planning period. Future Effects have the capacity to be translated into a marine system change by constituting or exacerbating a Pressure on marine systems in the planning period or in future planning periods.

The issue of ocean acidification (Doney et al. 2009) is a clear example of a Future Effect. In this case, the anthropogenically augmented pool of carbon dioxide currently in the Earth's atmosphere will, over the coming decades, equilibrate with the oceans. This equilibration will increase the acidity of the marine environment and lower the capacity of many calciferous marine 
Fig. 1. a: $t=0$ represents the time at which a decision is to be made, and $\mathrm{t}=\mathrm{T}$ represents the planning horizon, so that the planning period covers the range $0<\mathrm{t} \leq \mathrm{T}$. This figure adopts a similar approach to summarize the definition of the other class of endogenous constraints: Committed Behaviors showing causal relationships among a specific Driver activity (D), Pressure (P), and State $(S)$ or State change $(\Delta S)$. Where relevant, the superscript denotes the affected ecosystem compartment, with $\mathrm{M}=$ marine system and $\mathrm{N}=$ other (nonmarine) ecosystem compartments. The subscript indicates the time at which the relationship is manifested relative to the time at which a decision is made $(\mathrm{t}=0)$ and to the planning horizon $(\mathrm{t}=\mathrm{T})$.

b: Schematic diagram of Legacy Effects and Committed Behaviors, showing Drivers in green, Pressures in blue, and State in red.

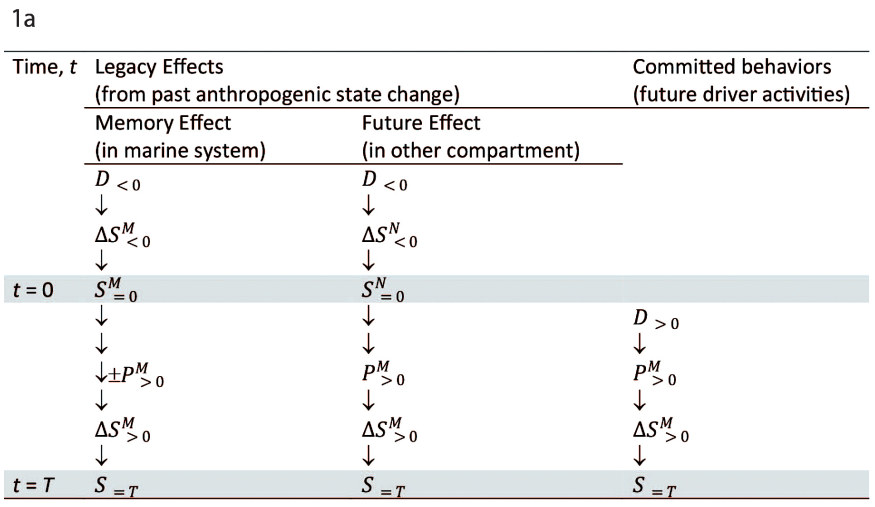

$1 \mathrm{~b}$

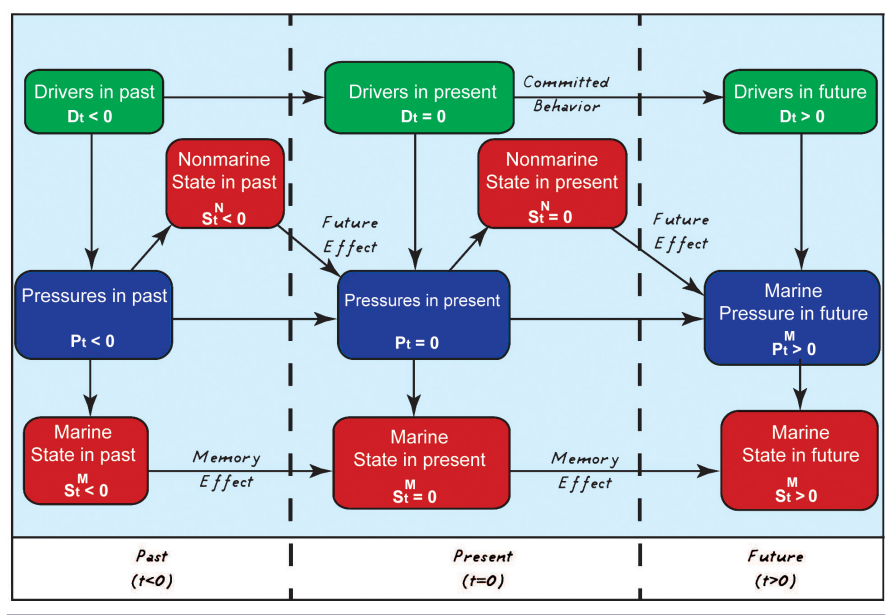

organisms to build shells. Modeling of the effects of potential mitigation policies indicates that maximum changes in ocean acidity will follow maximum atmospheric carbon dioxide inputs, with a time lag in the order of 80 years (Bernie et al. 2010). In the European context, this process poses a particular threat to cold water coral species, such as Lophelia pertusa, found at high latitudes and which provide essential fish habitat (Orr et al. 2005). In this way, the existing pool of carbon dioxide in the atmosphere poses a predictable and unalterable future threat to marine ecosystems, which should be considered when setting management targets. Counteracting ocean acidification requires global actions and is effectively exogenous at the local to regional scale.

\section{Committed Behaviors}

The ability of societies to manage the levels of Driver activities within a planning period can also impose constraints on management. Despite targets for the State of the marine environment, some Driver activities detrimental to marine environmental quality are unlikely to be curtailed or even to be amenable to significant change in the short to medium term. We refer to these activities as Committed Behaviors. Since they are associated with Driver activities in the planning period and can include activities designed to offset existing environmental problems, they may appear superficially to be within human control during the planning period but are only theoretically susceptible to Response measures. In reality, Committed Behaviors are substantially likely to persist, and thus are effectively embedded in the trajectory of future Driver activities for the planning period.

Committed Behaviors may be conceptualized as collective norms and activities that are not socially or politically feasible to alter in the short to medium term. We are concerned with behavior at a social level involving a more or less explicit consensus about how a system functions and where change would require collective support, potentially involving some balancing between perceived "winners" and "losers." Thus, we distinguish from individual behavior, which may be shaped by an individual's environmental attitudes and knowledge (e.g., Polonsky et al. 2012, MacPherson and Lange 2013) as well as the propensity towards biases and heuristics in decision-making under uncertainty (e.g., Tversky and Kahneman 1974, Strack and Deutsch 2004). We identify two broad sources for such Committed Behaviors: (1) explicit social/ political decisions that have been made prior to the planning period, effectively establishing a contract with agents such as firms whose actions have been based on these decisions, and (2) the methods for meeting demands for goods and services implicit in the operation of economic systems.

An example of an explicit social decision made at the political level lies in the UK's licensing of areas of the North Sea within its Exclusive Economic Zone for future development of offshore wind farms (Crown Estate 2012). This paves the way for future Driver activities in the form of turbine installation and operation. As in this case, explicit social decisions generally relate to specified activities with a specific spatial and temporal scope.

Another prominent example of explicit Committed Behaviors in Europe comes from the capture fisheries sector. EU fishing fleet capacity adjustment is supported under the structural policy of the Common Fisheries Policy (CFP) through a measure previously known as the Multi-Annual Guidance Programme (MAGP). This was designed to address the excess fishing capacity that underpins the ecological and economic overfishing of European stocks. It is evident that the policy of subsidized voluntary withdrawals has failed to meet its objective. As the European Parliament observed in 2002, commenting on the Commission's annual reports on the results of the MAGP for the fishing fleets at the end of 1997 (European Commission 1999) and 1999 (European Commission 2000a), the measures "have not brought about the desired balance between stocks and their exploitation largely owing to the failure of the majority of the 
Member States to comply with the MAGP" (European Commission 2000b). However, there was still a strong debate during the 2012 CFP reform process regarding the retention or withdrawal of subsidies, which resulted in the European Council deciding to retain them until 2017. Even if the will to change had become evident earlier, it is doubtful that the CFP commitment to a 10 -year policy cycle would have allowed substantive reform in the interim period. Following the recent vote agreeing on reforms to the CFP, it remains to be seen whether future actions will be subject to the same Committed Behaviors.

In contrast to explicit social/political decisions, behaviors associated with the operation of the economy to meet consumer demands are deeply ingrained in social systems after a long development process and generally persist as a result of market dynamics without the explicit direction of social decision-makers. Furthermore, they cover a wide range of activities involving complex relationships, which have become increasingly dispersed geographically through globalization. The ecological consequences of meeting consumer demands through this system, and the desire for economic growth that accompanies it, have long been recognized (e.g., Daly 1974, Arrow et al. 1995), but any radical and wide-ranging change, such as to a "steady-state economy" (Daly 1974) is not in prospect. Certainly, policy measures such as the MSFD are not contingent on such a change and are designed to operate within the existing system. The relevant point here is that over any reasonable planning horizon, the environmental manager should recognize the likely persistence of these economically driven behaviors and their consequences, subject to any technological developments and specific policy measures. Fig. 2 illustrates this type of relationship in the case of maritime freight transport and the level of general economic activity in Europe (note, for example, how a decline in shipping activity tracks the decline in GDP following the recent economic crisis). Therefore, even if the current global distribution of manufacturing and consumption sites were to remain, it is to be expected that this use of the sea will continue to track general economic activity in the absence of some radical development of a more cost-effective technology for the international transportation of goods. Thus, economic growth would be associated with increased Pressures from maritime freight transport, and these would be exacerbated by an expansion in international trade as new sites for manufacturing develop.

\section{LEGACY EFFECTS AND COMMITTED BEHAVIOR IN EUROPE'S SEAS}

Using the case studies described in Mee et al. (2015) and references therein, a matrix of Memory and Future Effects and MSFD descriptors of GEnS for Europe's regional seas was developed. Table 1 indicates the prevalence of Legacy and Future Effects in the case studies considered.

It is clear from the limited set of case studies considered here that Memory and Future Effects are widespread phenomena in Europe's regional seas. All of the case studies considered in Table 1 were subject to Memory or/and Future Effects that affected at least one but more commonly several of the GEnS descriptors. Memory Effects relate directly to descriptor 2 of the MSFD in the case studies of the non-native algae Caulerpa taxifolia in the Mediterranean (Pérez-Ruzafa et al. 2012) and of the predatory whelk Rapana venosa and comb jelly Mnemiopsis leydii in the
Fig. 2. Economic activity (blue) and maritime freight (red) in the EU15 countries. Sources of data: Eurostat (2012) data sets nama_gdp_c (GDP at market prices) and mar_mg_aa_cwh (gross weight of goods handled in all ports in billion tonnes). The Pearson correlation coefficient between the two variables across the years in this sample is 0.913 . For reasons of data availability, weight of goods handled is treated as a proxy for the number of trips and size of vessels, which are more likely to be relevant measures of the driver activity.

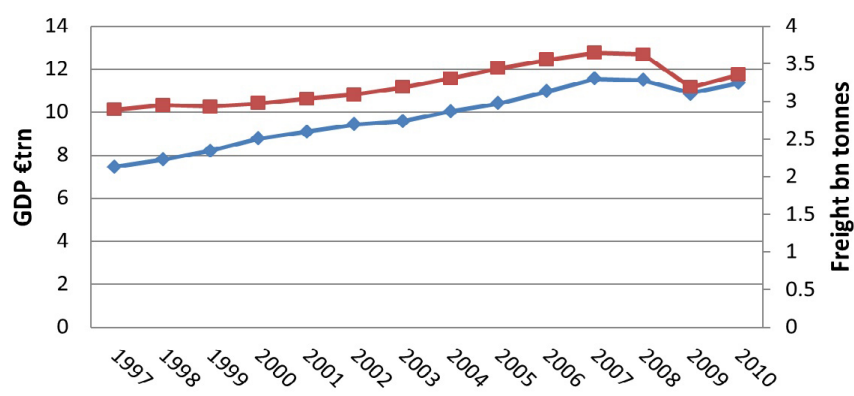

Table 1. Examples of the occurrence of Memory (M) and Future (F) Effects in European regional seas with respect to the Marine Strategy Framework Directive descriptors based on the case studies described in Mee et al. (2014). Footnotes indicate the specific topics covered and relevant literature for each case study.

\begin{tabular}{|c|c|c|c|c|}
\hline & $\begin{array}{l}\text { Black } \\
\text { Sea } \dagger\end{array}$ & $\begin{array}{l}\text { Baltic } \\
\text { Sea }\end{array}$ & $\begin{array}{c}\text { North East } \\
\text { Atlanticl } \\
\text { North Sea }\end{array}$ & $\begin{array}{l}\text { Mediterran- } \\
\quad \text { ean }\end{array}$ \\
\hline 1. Biodiversity & - & - & $F \S$ & - \\
\hline 2. Nonindigenous species & M & - & - & $\mathrm{M} \mid$ \\
\hline 3. Commercial species & M & M & $F \S$ & - \\
\hline 4. Food webs & M & M & - & - \\
\hline 5. Eutrophication & $\mathrm{M} / \mathrm{F}$ & M & - & - \\
\hline 6. Seafloor integrity & Mף & - & & - \\
\hline $\begin{array}{l}\text { 7. Alterations to } \\
\text { hydrography }\end{array}$ & . & - & $\mathrm{M} \#$ & - \\
\hline 8. Contaminants & - & - & - & $\mathrm{M} / \mathrm{F}+\dagger$ \\
\hline $\begin{array}{l}\text { 9. Contaminants in } \\
\text { seafood }\end{array}$ & - & - & - & $\mathrm{F}+\dagger$ \\
\hline 10. Litter & - & - & $M \S$ & - \\
\hline 11. Energy and noise & - & - & - & - \\
\hline \multicolumn{5}{|c|}{$\begin{array}{l}\text { † Regime shift in the Black Sea (Daskalov et al. 2010, Llope et al. 2011) } \\
\text { \$ Cod and eutrophication in the Baltic Sea (O’Higgins and Roth 2010, } \\
\text { Österblom et al. 2010) } \\
\text { § Cold water corals (Hall-Spencer et al. 2009, Tittensor et al. 2010, Söffker } \\
\text { et al. 2011) } \\
\text { | Caulerpa taxifola introduction to the Mediterranean (Pérez-Ruzafa et al. } \\
\text { 2012) } \\
\text { ๆ Rapana venosa (Black Sea Commission 2008, Knudsen and Koçak 2011) } \\
\text { \# North Sea wind farms (Busch et al. 2013) } \\
\text { † Contaminants in the Meditteranean (Gómez-Gutiérrez et al. 2007a, b) }\end{array}$} \\
\hline
\end{tabular}

Black Sea (Daskalov et al. 2007). In these cases, the arrival of nonindigenous species had profound effects on ecosystem functioning through ongoing predation and/or competition with native species. The presence of the comb jelly Mnemiopsis also 
Table 2. Examples of some relationships between implicit Committed Behaviors and the Marine Strategy Framework Directive descriptors.

\begin{tabular}{|c|c|c|c|c|c|c|c|c|c|c|c|}
\hline & $\begin{array}{c}1 \\
\text { Biodiversity }\end{array}$ & $\begin{array}{c}2 \\
\text { Nonindi- } \\
\text { genous } \\
\text { species }\end{array}$ & $\begin{array}{c}3 \\
\text { Commer- } \\
\text { cial } \\
\text { species }\end{array}$ & $\begin{array}{c}4 \\
\text { Food } \\
\text { webs }\end{array}$ & $\begin{array}{l}\quad 5 \\
\text { Eutrophic- } \\
\text { ation }\end{array}$ & $\begin{array}{c}6 \\
\text { Seafloor } \\
\text { integrity }\end{array}$ & $\begin{array}{c}7 \\
\text { Alterations } \\
\text { to } \\
\text { hydrogra- } \\
\text { phy } \\
\end{array}$ & $\begin{array}{c}8 \\
\text { Contami- } \\
\text { nants }\end{array}$ & $\begin{array}{c}9 \\
\text { Contami- } \\
\text { nants in } \\
\text { seafood }\end{array}$ & $\begin{array}{c}10 \\
\text { Energy } \\
\text { and noise }\end{array}$ & $\begin{array}{c}11 \\
\text { Litter }\end{array}$ \\
\hline Shipping & $X$ & $X$ & & & & $\mathrm{X}$ & $\mathrm{X}$ & $X$ & & $X$ & $X$ \\
\hline Fishing & $\mathrm{X}$ & & $\mathrm{X}$ & $\mathrm{X}$ & $\mathrm{X}$ & $\mathrm{X}$ & & $\mathrm{X}$ & & $\mathrm{X}$ & $\mathrm{X}$ \\
\hline Aquaculture & $X$ & $\mathrm{X}$ & $\mathrm{X}$ & $\mathrm{X}$ & $\mathrm{X}$ & $\mathrm{X}$ & $\mathrm{X}$ & $\mathrm{X}$ & $X$ & $\mathrm{X}$ & $\mathrm{X}$ \\
\hline Agriculture & $\mathrm{X}$ & & & $\mathrm{X}$ & $X$ & $\mathrm{X}$ & & $\mathrm{X}$ & $\mathrm{X}$ & & \\
\hline Energy & & & & $\mathrm{X}$ & $\mathrm{X}$ & $\mathrm{X}$ & $\mathrm{X}$ & & & $\mathrm{X}$ & $\mathrm{X}$ \\
\hline $\begin{array}{l}\text { Construction and } \\
\text { urban development }\end{array}$ & & & & & $\mathrm{X}$ & $\mathrm{X}$ & $X$ & $\mathrm{X}$ & $\mathrm{X}$ & $\mathrm{X}$ & $\mathrm{X}$ \\
\hline Tourism & & $\mathrm{X}$ & & & & $\mathrm{X}$ & & $\mathrm{X}$ & $X$ & $\mathrm{X}$ & $\mathrm{X}$ \\
\hline Mining & & & & & & $\mathrm{X}$ & & $\mathrm{X}$ & $X$ & $\mathrm{X}$ & \\
\hline Industry & & & & & & & & $\mathrm{X}$ & $\mathrm{X}$ & & \\
\hline
\end{tabular}

results in Memory Effects on descriptor 3, through competition with juveniles of commercial species, and descriptor 5, through predation on grazing zooplankton, while the whelk Rapana diminishes sea floor integrity through predation on native mussel reefs (Black Sea Commission 2008). Memory Effects are also associated with commercial species in the Black and Baltic Seas through historical overfishing and the effects of eutrophication, including altered macrofaunal composition in the Black Sea, persistent pools of nutrients in the Baltic Sea, and their effects on water quality. In the North Sea, Memory Effects in the form of alterations to hydrography occur and will increase with the construction of semipermanent offshore wind farm structures. The Memory Effect caused by the persistence of marine litter caught in cold water coral reefs is illustrated in Fig. 3.

Fig. 3. Cold water coral reef with entangled fishing gear, indicating the Memory Effect of marine litter relevant to descriptor 11 of the Marine Strategy Framework Directive (Söffker et al. 2011). Nonbiodegradable ropes are likely to remain entangled in the reefs for decades, at the least.

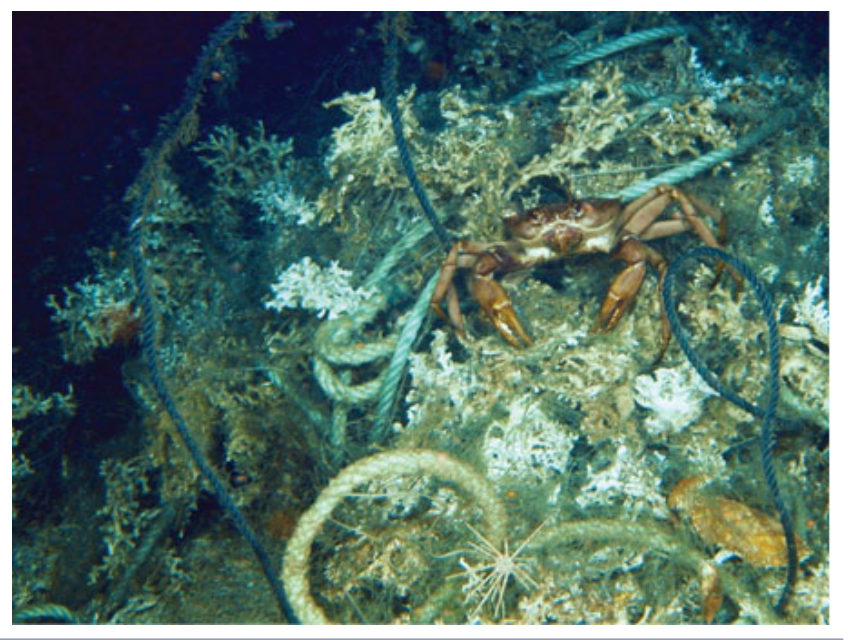

The examples in Table 1 illustrate three different types of Future Effect: those related to atmospheric, terrestrial, and sedimentary nonmarine pools. Anthropogenic sources of carbon dioxide in the atmosphere will result in ocean acidification. Warming of the oceans will alter biogeochemical processes, which will cause the release of accumulated contaminants in sediments back into the marine environment (see Schiedek et al. 2007 for a review). The Future Effects associated with the Black Sea case study are associated with pools of nutrients currently outside the marine environment where reservoirs of silica are bound up in the lakes created by the damming of the River Danube (Humborg et al. 1997); this silica will ultimately be transported to the Black Sea at an unknown time in the future.

A second matrix relating sectoral Drivers (implicit Committed Behaviors) and specific practices in a particular sector (e.g., dredging, trawling) to the GEnS descriptors was developed. Table 2 shows sectors that affect particular descriptors of GEnS based on the case studies described in Mee et al. (2015). A more detailed account of the interactions between Committed Behaviors and descriptors can be found in Appendix 1.

Each of the sectors presented in Table 2 may be considered to include Committed Behavior, as it is not politically feasible to change these activities in the short to medium term. The Drivers listed in Table 2 exert a range of different Pressures on European marine ecosystems, which affects all of the GEnS descriptors. Table 2 is not intended to be an exhaustive list of all Pressures associated with all Drivers, which would be beyond the scope of a single manuscript; rather, it illustrates the multiple relationships identified in a limited suite of case studies (as described by Mee et al. 2015).

Shipping affects biodiversity (D1) through the introduction of nonindigenous species (D2) and fouling organisms. The past use of antifoulants (e.g., tributyltin) also affected biodiversity (D1) by disrupting the reproduction of gastropods and causing consequent changes in community structure (Alzieu 2000, Lewis and Ford 2012). Dredging for maritime transport affects seafloor integrity (D6) and alters hydrography (D7), while antifoulants, oils spills, and ship emissions contribute to contaminants (D8) 
that may eventually taint seafood (D9). The noise (D10) and litter (D11) from ships are additional maritime sector effects on descriptors.

Fishing affects biodiversity (D1), commercial species (D3), and food webs (D4) by the selective removal of certain species, notwithstanding bycatch. There is also a relationship with eutrophication (D5), as fishing exerts pressures farther down the food chain by removing top predators. Bottom trawling, in particular, affects seafloor integrity (D6), and fishing port structures affect hydrography (D7). Antifoulants and ship emissions cause contamination (D8), while noise (D10) and litter (D11) are also a feature of the fishing fleet.

The aquaculture sector affects biodiversity (D1) directly by the introduction of nonindigenous species (D2) and indirectly by changing market demand and the resulting capture fisheries for certain wild species. Aquaculture may also affect food webs (D4) at a global scale. For example, the fish meal produced in Peru and Chile from the wild anchoveta fisheries is transported around the world and introduced to marine ecosystems at distant aquaculture sites. At the local scale, the removal of phytoplankton by cultured filter-feeding bivalves affects food web structure. Furthermore, this may have an attenuating effect on eutrophication (D5) (Ferreira et al. 2009). Feeding caged fish may have an aggravating effect on eutrophication (D5). Digging for bivalves (e.g., clams), and the construction of aquaculture ponds affect seafloor integrity (D6) and hydrography (D7) in coastal areas. The use of potential contaminants (D8), such as antibiotics, pesticides, and colorants, in intensive aquaculture can have an effect on seafood (D9). Motor boats for offshore aquaculture produce noise (D10), and nets, ropes, and buoys from aquaculture produce litter(D11).

Agriculture affects biodiversity (D1) mainly through eutrophication (D5) when excess use of fertilizers causes changes in the stoichiometry of nutrients such as $\mathrm{N}$ and $\mathrm{P}$ that alter the composition of the phytoplankton, the food web (D4), and therefore commercial catches (D3). Dams built to retain water for irrigation alter hydrography (D7) and retain sediment, thereby compromising seafloor integrity (D6). The use of contaminants (D8) in agriculture (pesticides, herbicides) and animal rearing (antibiotics, hormones, pesticides) may eventually contaminate seafood (D9).

Biodiversity (D1) is affected by the energy sector because offshore structures act as artificial reefs (Wilson and Elliott 2009). Hydroelectric dams affect eutrophication (D5) by retaining silicon and thereby changing nutrient stoichiometry and altering the composition of phytoplankton (Humborg et al. 1997). Seafloor integrity (D6) is affected by the installation of offshore structures, which alter hydrography (D7) by causing stirring. Noise (D10) is caused by activities around offshore installations, which may also contribute to marine litter (D11).

Mining, in particular sand and gravel extraction, affects seafloor integrity (D6) and is a source of noise (D10). Mining may also release metal contaminants (D8) (e.g., Covelli et al. 2001) that may accumulate in seafood (D9) (Baishaw et al. 2007). This is also true for industrial activities that cause contamination (D8 and D9).

Construction, urban development, and tourism affect biodiversity (D1) through changes in coastal land use, and especially land reclamation. In addition, coastal cruising may introduce nonindigenous species (D2) through ballast water, and fouling organisms. Domestic effluent contributes to eutrophication (D5) and may contain contaminants (D8) such as hormones, antibiotics, and other lifestyle pollutants that may eventually contaminate seafood (D9). Beach nourishment and coastal defence structures affect seafloor integrity (D6) and disrupt sediment cells and hydrography (D7), while large cruise ships resuspend sediment (D6). Litter (D11) may originate from urban beaches and cruise ships.

\section{DISCUSSION}

We have formalized the concept of legacy as a constraint on policy and management planning, but the concept has wider ramifications for the analysis of interactions between human and ecological systems.

Within the decision context of the MSFD, the environmental assessment, targets, and indicators are set at a national level. The MSFD descriptors focus on the environmental degradation of the natural environment, as do the OSPAR (2010) and HELCOM (2010) assessment reports. These do not, at present, integrate the need for a meaningful and appropriate classification system that can integrate ecosystem services and thereby inform the political process (Fisher et al. 2009). More socially relevant assessments would focus on the definitions and characteristics that are necessary to protect or restore future welfare. The policy requirements for decisions on future programs of measures cannot exclude ecosystem imbalances for the sole reason of Legacy or Commitment but may wish to adapt to the changes or actively offset the impacts (Welfare effects). The concepts we have developed can form the foundation of a meaningful and appropriate classification of ecosystem processes and services that may be used practically in decision-making.

While Legacy Effects represent limitations in the capacity of ecosystems to deal with anthropogenic pressures, for example, through assimilation of pollutants, Committed Behaviors lie entirely in DPSWR's human domain and are thus more susceptible to social action. However, their likely persistence represents a form of inertia in social systems that is particularly acute in the case of behaviors connected with economic activity. Consequently, the design of Responses intended to alter Committed Behaviors entails recognition of the forces shaping relevant economic activities and the scale at which they operate.

Driver activities ultimately manifest consumption demands and how markets are mobilized to meet those demands, respectively corresponding to the individual and institutional elements. Thus, two broad forms of Response measure are highlighted: (1) changing the level or pattern of consumption, for example, through incentivizing individuals or influencing their preferences for the consumption of animal protein, and (2) changing systems of production, for example, through technological innovation to limit nutrient inputs. The detail of such responses goes beyond the current scope, but these examples illustrate the long-term nature of the changes involved, and hence the continuing challenge of social inertia - a challenge that is likely to be exacerbated by the underlying drivers of population growth, increasing affluence, and globalization.

The scale of action required to implement social change adds further complexity to the challenge. Although it is argued that environmental resources can be most sustainably managed by 
locally devised, adaptive, institutions (Ostrom 2005, 2009), few social-ecological systems are sufficiently closed at a local scale for this to be possible. Certainly, in the case of marine ecosystems, social-ecological interactions occur at scales beyond conventional political boundaries. Therefore, response is required at the supranational level, as in the case of the MSFD. At least in this case, it is arguable that the inertia of large institutions has been overcome in the sense of achieving a social decision on an objective. However, it remains to be seen whether the social changes required for its successful achievement can be implemented in the member states by the 2020 deadline. Experience with the Urban Waste Water Treatment Directive suggests that full implementation may take decades (e.g., Smith 2000).

Based on our proposed classification and the case studies considered, we suggest that the most significant implications arise in the following areas:

\section{Awareness}

The MSFD (Art. 8) requires an assessment of the status of marine waters. Given the widespread occurrence of Memory and Future Effects and their lack of recognition in current assessments, there is a clear need to promote an understanding of these effects among scientists and decision-makers involved in marine management. Assessments should involve more than simply an assessment of a pollutant concentration or the size of a fish population, and should integrate temporal effects. Embedded within this assessment, Memory Effects need to be determined. Is a state change permanent or transient? Would measures to address a Pressure cause a State change or not, and over what possible timescale?

Awareness of Memory Effects is not only essential for the marine manager but also for communication by marine managers with stakeholders. Stakeholders need to understand the opportunities for, and limits of, change in marine systems due to Memory Effects, and the potential timescales for change.

\section{Developing indicators and targets}

The MSFD requires the establishment of indicators (Art. 10) to guide the development of measures and monitoring. It is important to understand the implications of Memory Effects in developing indicators as required by the MSFD, in particular, where such indicators are established with respect to a baseline metric. If the baseline includes a Memory Effect, this might result in a target or indicator that is realistic in management but ecologically irrelevant. For example, if a target is set according to the number of 25-year-old cod in the North Sea, and the oldest cod in the sea is currently 12 years old, by definition, the target could not be met for at least another 13 years.

While various Memory Effects have been identified and some have been studied in detail, some are understood only in general terms. Therefore, identifying clear indicators and integrating Memory Effects within monitoring is necessary to move from conceptual understanding to generating sufficient information for practical application. Research and modeling are also required to better assess the timeframes for temporal effects.

Similarly, in the setting of targets under the MSFD (Art. 9), understanding the role of Memory Effects is critical in determining the future marine environment that is achievable.
Without this understanding, targets could be too ambitious (e.g., seeking to remove Memory Effects) or not sufficiently ambitious.

\section{Inclusion in programs of measures}

The actions to be taken forward to achieve the objectives of the MSFD within marine strategies are to be set out in programs of measures (Art. 13). In establishing such measures, it is critically important to ensure that Memory Effects and Future Effects are understood with respect to specific pressures in specific marine regions. This location-specific knowledge can enable the adoption of measures that would be most effective in tackling individual pressures and can help avoid measures that would be ineffective and would result in unnecessary costs.

Furthermore, understanding the interaction between ongoing pressures and Legacy Effects may change the measures considered appropriate for some pressures (e.g., reflecting a change understanding of the scale of the impact of those pressures). With regard to Committed Behavior, measures also need to target the key technical aspects of "de-linking" (De Bruyn and Opschoor 1997), which would most alleviate the pressures resulting from the Drivers.

\section{Reducing the effects of Drivers}

While Committed Behaviors constitute a constraint on policy and management decisions, the extent of their impact needs to be assessed in terms of the Pressures they exert on marine ecosystems. Consequently, the decision-maker should recognize the scope for de-linking Driver activities and the Pressures they exert: ultimately, it is the extent of Pressure rather than the level of Driver activity that leads to change in environmental State and consequent changes in Welfare. For example, more stringent treatment of urban waste water has decreased the nutrient loading to rivers and coastal seas without requiring changes in patterns of consumption by citizens. Reducing the Pressures caused by Drivers presents opportunities for the decision-maker to implement Response measures that will limit the alterations to ecosystem State resulting from Committed Behaviors. Nevertheless, without complete de-linking, the Driver activity remains a source of State change in the planning period.

Some Future Effects are strong and reflect the robustness of certain human activities in delivering social and economic needs. For example, agricultural activity causes a number of impacts on marine systems (e.g., Rosenberg 1985, Savchuk 2005, Mee et al. 2005), but notwithstanding possible future trends in the import of agricultural products, it is highly unlikely that activity in this sector will be significantly curtailed in Europe given the historical emphasis on food security within Europe (O'Higgins and Roth 2011). For Committed Behaviors, the challenge for marine managers (and others) is to reduce the Pressure caused by the Driver activity without necessarily reducing the level of the Driver. Ensuring agricultural productivity can continue with lower fertilizer and pesticide inputs would deliver such a reduction. Similarly, altering fishing behavior to implement sustainable catch levels and so deliver maximum sustainable yield would also de-link the Driver and Pressure. Measures under the Directive, however, do not specifically address the innovation required to de-link Drivers from Pressures.

\section{Implications for economic analysis}

The idea of system legacy has implications for the economic analysis of the environment and associated management 
decisions in that there is the risk of overestimating the current capital value of future ecosystem service provision if Legacy Effects are not taken into account. Furthermore, where Legacy Effects exist, there is a temporal disjuncture between "historic benefits" from the Driver activities that created them and "future costs" from the resulting change in Welfare. This disjuncture may lead to a mismatch in terms of recognition in the cost-benefit analysis of a current environmental management decision. In such a case, generally, historic benefits should be treated as irrelevant to the analysis (they are "sunk" in that they have been enjoyed and are unaffected by the decision). On the other hand, future costs will be relevant to the extent that their level would be influenced by the decision under review. Thus, some or all of the future costs may feature in the decision analysis, while the associated historic benefits do not.

This type of mismatch reflects the prospective nature of costbenefit analysis and the reality facing the decision-maker in that their decision may affect future costs but not historic benefits. Nevertheless, addressing other policy-relevant issues may involve recognizing those benefits. For example, policy-makers concerned about the distribution of benefits and costs, particularly where there is an extended temporal disjuncture, may be interested in an ex post comparison of Driver benefits and the associated costs arising from environmental change.

\section{CONCLUSIONS}

While the importance of spatial considerations in applying an ecosystem approach to marine management has been widely recognized (e.g., O’Higgins et al. 2010, Alexander et al. 2012, Jordan et al. 2012), temporal aspects have received less focus. We have described and defined several important and widespread temporal characteristics of social-ecological systems that constrain our ability to manage them; these are Legacy Effects (and the subcategories of Memory and Future Effects), and implicit and explicit Committed Behaviors. These concepts present a formal analytical framework to allow us to integrate considerations of our past activities, through their current and future impacts, into decision-making, thus providing a basis for addressing intergenerational equity in environmental management. In some cases, the costs of environmental remediation may be justified only when offset against benefits that were experienced by a previous generation (O'Higgins and Roth 2011).

The importance of Legacy Effects and Committed Behaviors is not limited to the implementation of the MSFD but has global implications concerning historical and future costs and benefits, where and when they occur, and how they can be efficiently and effectively managed. While conceptual frameworks that abstract from time, such as DPSWR, are useful tools in analyzing the relationship between human activities and their Impacts, they may create the impression that such relationships are near contemporaneous, thus concentrating management action on future human activities. The classification of temporal effects we have presented adds an important perspective to such analyses by highlighting to the environmental decision-maker that effective action is not only a product of managing future human activities. It should also take account of constraints imposed by the environmental consequences of past activities and the processes underlying those activities that remain embedded in social systems.
Responses to this article can be read online at: http://www.ecologyandsociety.org/issues/responses. $\mathrm{php} / 6507$

\section{Acknowledgments:}

The research leading to these results received funding from the European Community's Seventh Framework Programme [FP7/2007-2013] under grant agreement number 226675. The KnowSeas project is affiliated with LOICZ and LWEC. We would like to thank the two anonymous reviewers and the subject editor for their helpful comments and suggestions.

\section{LITERATURE CITED}

Alexander, K., R. Janssen, G. Arciniegas, T. O'Higgins, T. Eikelboom, and T. Wilding. 2012. Interactive marine spatial planning: siting tidal energy arrays around the Mull of Kintyre. PloS One [online] URL: http://dx.plos.org/10.1371/journal. pone. 0030031

Alzieu, C. 2000. Impact of tributyltin on marine invertebrates. Ecotoxicology 9:71-76. http://dx.doi.org/10.1023/A:1008968229409

Andersen, T., J. Carstensen, E. Hernández-García, and C. M. Duarte. 2009. Ecological thresholds and regime shifts: approaches to identification. Trends in Ecology \& Evolution 24:49-57. http:// dx.doi.org/10.1016/j.tree.2008.07.014

Apeti, D. A., G. G. Lauenstein, J. D. Christensen, K. Kimbrough, W. E. Johnson, M. Kennedy, and K. G. Grant. 2010. A historical assessment of coastal contamination in Birch Harbor, Maine based on the analysis of mussels collected in the 1940s and the Mussel Watch Program. Marine Pollution Bulletin 60:732-742. http://dx.doi.org/10.1016/j.marpolbul.2009.11.021

Arrow, K., B. Bolin, R. Costanza, P. Dasgupta, C. Folke, C. S. Holling, B. O. Jansson, S. Levin, K. G. Mäler, C. Perrings, and D. Pimental. 1995. Economic growth, carrying capacity, and the environment. Science 268:520-521. http://dx.doi.org/10.1126/ science.268.5210.520

Atkins, J. P., D. Burdon, M. Elliott, A. J. Gregory. 2011. Management of the marine environment: integrating ecosystem services and societal benefits with the DPSIR framework in a systems approach. Marine Pollution Bulletin 62:215-226. http:// dx.doi.org/10.1016/j.marpolbul.2010.12.012

Baishaw, S., J. Edwards, B. Draughty, and K. Ross. 2007. Mercury in seafood: mechanisms of accumulation and consequences for consumer health. Reviews on Environmental Health 22:91-113. http://dx.doi.org/10.1515/REVEH.2007.22.2.91

Bernie, D., J. Lowe, T. Tyrrell, and O. Legge. 2010. Influence of mitigation policy on ocean acidification. Geophysical Research Letters 37:1-5. http://dx.doi.org/10.1029/2010GL043181

Black Sea Commission. 2008. State of the environment of the Black Sea (2001-2006/7). T. Oguz, editor. Publications of the Commission on the Protection of the Black Sea Against Pollution (BSC) 2008-3, Istanbul, Turkey.

Borja, Á. 2006. The new European Marine Strategy Directive: 
difficulties, opportunities, and challenges. Marine Pollution Bulletin 52:239-242. http://dx.doi.org/10.1016/j.marpolbul.2005.12.007

Borja, Á., M. Elliott, J. Carstensen, A.-S. Heiskanen, and W. van de Bund. 2010a. Marine management - towards an integrated implementation of the European Marine Strategy Framework and the Water Framework Directives. Marine Pollution Bulletin 60:2175-2186. http://dx.doi.org/10.1016/j.marpolbul.2010.09.026

Borja, Á., D. M. Dauer, M. Elliott, and C. A. Simenstad. $2010 b$. Medium- and long-term recovery of estuarine and coastal ecosystems: patterns, rates and restoration effectiveness. Estuaries and Coasts 33:1249-1260. http://dx.doi.org/10.1007/s12237-010-9347-5

Borja, Á., D. M. Dauer, and A. Grémare. 2012. The importance of setting targets and reference conditions in assessing marine ecosystem quality. Ecological Indicators 12:1-7. http://dx.doi. org/10.1016/j.ecolind.2011.06.018

Busch, M., A. Kannen, S. Garth, and M. Jessop. 2013. Consequences of a cumulative perspective on marine environmental impacts: offshore wind farming and seabirds at the North Sea scale in context of the EU Marine Strategy Framework Directive. Ocean \& Coastal Management 71:213-224. http://dx. doi.org/10.1016/j.ocecoaman.2012.10.016

Cardoso, A. C., S. Cochrane, H. Doemer, J. G. Ferreira, F. Galgani, C. Hagebro, G. Hanke, N. Hoepffner, P. D. Keizer, R. Law, S. Olenin, G. J. Piet, J. Rice, S. I. Rogers, F. Swartenbroux, M. L. Tasker, and W. van de Bund. 2010. Scientific support to the European Commission on the Marine Strategy Framework Directive. Management Group Report. EUR 24336 EN - Joint Research Centre, Luxembourg: Office for Official Publications of the European.

Checkland, P. B., and J. Poulter. 2006. Learning for action: a short definitive account of soft systems methodology and its use for practitioners, teachers and students. John Wiley and Sons Ltd., Chichester, UK.

Connor, M. S., J. A. Davis, J. Leatherbarrow, B. K. Greenfield, A. Gunther, D. Hardin, T. Mumley, J. J. Oram, and C. Werme. 2007. The slow recovery of San Francisco Bay from the legacy of organochlorine pesticides. Environmental Research 105:87-100. http://dx.doi.org/10.1016/j.envres.2006.07.001

Cooper, P. 2013. Socio-ecological accounting: DPSWR, a modified DPSIR framework, and its application to marine ecosystems. Ecological Economics 94:106-115. http://dx.doi. org/10.1016/j.ecolecon.2013.07.010

Covelli, S., J. Faganeli, M. Horvat, and A. Brambati. 2001. Mercury contamination of coastal sediments as the result of longterm cinnabar mining activity (Gulf of Trieste, northern Adriatic Sea). Applied Geochemistry 16:541-558. http://dx.doi.org/10.1016/ $\underline{\mathrm{S} 0883-2927(00) 00042-1}$

Crown Estate. 2012. UK offshore wind report 2012. [online] URL: http://www.ecoconnect.org.uk/publications/uk-offshore-wind-report-2012/

CSIRO. 2003. Natural values: exploring options for enhancing ecosystem services in the Goulburn Broken Catchment. CSIRO Sustainable Ecosystem Programme. ISBN: 095808457 2, pp. 1161.

Daly, H. E. 1974. The economics of the steady-state. American
Economic Review 64:15-21.

Daskalov, G. M., A. N. Grishin, S. Rodionov, and V. Mihneva. 2007. Trophic cascades triggered by overfishing reveal possible mechanisms of ecosystem regime shifts. Proceedings of the National Academy of Science of the United States of America 104:10518-10523. http://dx.doi.org/10.1073/pnas.0701100104

Daskalov G., A. Gümüş, V. Maximov, M. Panayotova, G. Radu, V. Raykov, V. Shlyakhov, M. Zengin, H. J. Rätz, R. Scott, and J. N. Druon. 2010. Review of scientific advice for 2010 - part $3 \mathrm{~b}$. Advice on stocks of interest to the European Community in the Black Sea Scientific, Technical and Economic Committee for Fisheries, Joint Research Centre - Institute for the Protection and Security of the Citizen Luxembourg: Office for Official Publications of the European Communities 2010 EUR Scientific and Technical Research series. http://stecf.jrc.ec.europa.eu http:// dx.doi.org/10.2788/80318

De Bruyn, S. M., and J. B. Opschoor. 1997. Developments in the throughput-income relationship: theoretical and empirical observations. Ecological Economics 20:255-268. http://dx.doi. org/10.1016/S0921-8009(96)00086-9

De Young, B., M. Barange, G. Beaurgrand, R. Harris, R. I. Perry, M. Sheffer, and F. Werner. 2008. Regime shifts in marine ecosystems: detection prediction and management. Trends in Ecology \& Evolution 23:402-409. http://dx.doi.org/10.1016/j. tree.2008.03.008

Doney, S. C., W. M. Balch, V. J. Fabry, and R. A. Feely. 2009. Ocean acidification: a critical emerging problem for the ocean sciences. Oceanography 22:16-25. http://dx.doi.org/10.5670/ oceanog.2009.93

Duarte, C. M., D. J. Conley, J. Carstensen, and M. SánchezCamacho. 2009. Return to Neverland: shifting baselines affect eutrophication restoration targets. Estuaries and Coasts 32:2936. http://dx.doi.org/10.1007/s12237-008-9111-2

Elliott, M. 2002. The role of the DPSIR approach and conceptual models in marine environmental management: an example for offshore wind power. Marine Pollution Bulletin 44:iii-vii. http:// dx.doi.org/10.1016/S0025-326X(02)00146-7

Elliott, M. 2011. Marine science and management means tackling exogenic unmanaged pressures and endogenic managed pressures — a numbered guide. Marine Pollution Bulletin 62:651-655. http:// dx.doi.org/10.1016/j.marpolbul.2010.11.033

Environmental Protection Agency. (EPA). 2009. Valuing the protection of ecological systems and services. A report of the EPA science advisory board. U.S. Environmental Protection Agency, Washington, D.C., USA. EPA-SAB-09-012.

European Commission. 1999. Annual report from the Commission to the Council and to the European Parliament on the results of the multi-annual guidance programmes for the fishing fleets at the end of 1997. (COM(1999) 175 _ C5-0109/1999_ 1999/2112(COS)).

European Commission. 2000a. Annual report from the Commission to the Council and to the European Parliament on the results of the multi-annual guidance programmes for the fishing fleets at the end of 1999. (COM(2000) 738 _ C5-0107/2001 _ 2001/2056(COS)). 
European Commission. 2000b. European Parliament resolution on the annual report from the Commission to the Council and the European Parliament on the results of the multiannual guidance programmes for the fishing fleets at the end of 1997 and 1999 (COM (2000) 738 - C5-0107/2001 - 2001/2056(COS)), Official Journal of the European Communities EN 14.3.2002, C 65 E/386.

European Commission. 2008. Directive 2008/56/EC of the European Parliament and of the Council of 17 June 2008 establishing a framework for community actions in the field of marine environmental policy (Marine Strategy Framework Directive). Official Journal of the European Communities L164/19 25.06.2008.

European Commission, 2010. Commission decision of 1 September 2010 on criteria and methodological standards on good environmental status of marine waters (notified under document C(2010) 5956)(2010/477/EU)). Official Journal of the European Union L232, $12 \mathrm{e} 24$.

Eurostat. 2012. http://epp.eurostat.ec.europa.eu/portal/page/ portal/statistics/search database

Ferriera, J. G., A. Sequeira, A. J. S. Hawkins, A. Newton, T. D. Nickell, R. Pastres, J. Forte, A. Bodoy, and S. B. Bricker. 2009. Analysis of coastal and offshore aquaculture: application of the FARM model to multiple systems and shellfish species. Aquaculture 289:32-41. http://dx.doi.org/10.1016/j. aquaculture.2008.12.017

Fisher, B., R. K. Turner, and P. Morling. 2009. Defining and classifying ecosystem services for decision making. Ecological Economics 68:643-653. http://dx.doi.org/10.1016/j.ecolecon.2008.09.014

Folke, C., S. Carpenter, B. Walker, M. Scheffer, T. Elmqvist, L. Gunderson, and C. S. Holling. 2004. Regime shifts, resilience, and biodiversity in ecosystem management. Annual Review of Ecology, Evolution, and Systematics 35:557-581. http://dx.doi. org/10.1146/annurev.ecolsys.35.021103.105711

Gómez-Gutiérrez, A., E. Garnacho, J. M. Bayona, and J. Albaigés. 2007a. Assessment of the Mediterranean sediments contamination by persistent organic pollutants. Environmental Pollution 148:396-408. http://dx.doi.org/10.1016/j.envpol.2006.12.012

Gómez-Gutiérrez, A., E. Garnacho, J. M. Bayona, and J. Albaigés. 2007b. Screening ecological risk assessment of persistent organic pollutants in Mediterranean Sea sediments. Environmental International 33:867-876. http://dx.doi.org/10.1016/ j.envint.2007.04.002

Hall-Spencer J. M., M. Tasker, M. Soffker, S. Christiansen, S. Rogers, M. Campbell, and K. Hoydal. 2009. Design of Marine Protected Areas on high seas and territorial waters of Rockall Bank. Marine Ecology Progress Series 397:305-308. http://dx.doi. org/10.3354/meps08235

HELCOM. 2010. Ecosystem health of the Baltic Sea 2003-2007: HELCOM Initial Holistic Assessment Baltic Sea Environment Proceedings 122. HELCOM, Helsinki, Finland.

Humborg, C., V. Ittekkot, A. Cociasu, and B. V. Bodungen. 1997. Effect of Danube River dam on Black Sea biogeochemistry and ecosystem structure. Nature 386:385-388. http://dx.doi. org/10.1038/386385a0
ICES. 2010. Report of the ICES/HELCOM Working Group in integrated assessments of the Baltic Sea (WGIAB). 19-23 April 2010, ICES Headquarters, Copenhagen, Denmark.

Jordan, S. J., T. O'Higgins, and J. A. Dittmar. 2012. Ecosystem services of coastal habitats and fisheries: multiscale ecological and economic models in support of ecosystem-based management. Marine and Coastal Fisheries: Dynamics, Management, and Ecosystem Science 4:573-586. http://dx.doi. org/10.1080/19425120.2012.703162

Knudsen, S., and H. Koçak. 2011. Through boom and bust. coping with poverty in sea snail fisheries on the Turkish Black Sea coast. In S. Jentoft and A. Eide, editors. Poverty mosaics. Realities and prospects in small scale fisheries. Springer-Verlag, Dordrecht, The Netherlands. http://dx.doi.org/10.1007/978-94-007-1582-0_11

Lewis, C., and A. T. Ford. 2012. Infertility in male aquatic invertebrates: a review. Aquatic Toxicology 120:79-89. http://dx. doi.org/10.1016/j.aquatox.2012.05.002

Llope M., G. M. Daskalov, T. A. Rouyer, V. Mihneva, K.-S. Chan, A. N. Grishin, and N. C. Stenseth. 2011. Overfishing of top predators eroded the resilience of the Black Sea system regardless of the climate and anthropogenic conditions. Global Change Biology 17:1251-1265. http://dx.doi.org/10.1111/j.1365-2486.2010.02331. $\underline{x}$

MacPherson, R., and I. Lange. 2013. Determinants of green electricity tariff uptake in the UK. Energy Policy 62:920-933. http://dx.doi.org/10.1016/j.enpol.2013.07.089

Mee, L., P. Cooper, A. Kannen, A. J. Gilbert, and T. O'Higgins. 2015. Sustaining Europe's seas as coupled social-ecological systems. Ecology and Society, in press Vol. 20 Issue1.

Mee, L. D., J. Friedrich, and M. T. Gomoiu. 2005. Restoring the Black Sea in times of uncertainty. Oceanography 18:100-111. http://dx.doi.org/10.5670/oceanog.2005.45

Mee, L. D., R. L. Jefferson, D. d'A. Laffoley, and M. Elliott. 2008. How good is good? Human values and Europe's proposed Marine Strategy Directive. Marine Pollution Bulletin 56:187-204. http:// dx.doi.org/10.1016/j.marpolbul.2007.09.038

Milankovich, M. 1941. Kanon der Erdbestrahlung und seine Anwendung auf das Eiszeitenproblem: Special Publications, v. 132, Section of Mathematics and Natural Sciences, v. 33, Belgrade, Königliche Serbische Akademie.

Millennium Ecosystem Assessment. 2003. Ecosystems and human well-being: a framework for assessment. Island Press, Washington, D.C., USA.

Munkes, B. 2005. Eutrophication, phase shift, the delay and the potential return in the Greifswalder Bodden, Baltic Sea. Aquatic Sciences 67:372-381. http://dx.doi.org/10.1007/s00027-005-0761$\underline{x}$

Murray, J. W., Z. Top, and E. Özsoy. 1991. Hydrographic properties and ventilation of the Black Sea. Deep Sea Research Part A. Oceanographic Research Papers 38:S663-S689. http://dx. doi.org/10.1016/S0198-0149(10)80003-2

Nye J. A., M. R. Baker, R. Bell, A. Kenny, K. Halimeda 
Kilbourne, K. D. Friedland, E. Martino, M. M. Stachura, K. S. Van Houtan, and R. Wood. 2014. Ecosystem effects of the Atlantic Multidecadal Oscillation. Journal of Marine Systems http://dx.doi.org/10.1016/j.jmarsys.2013.02.006

O’Higgins, T. G., S. P. Ferraro, D. D. Dantin, S. J. Jordan, and M. M. Chintala. 2010. Habitat scale mapping of fisheries ecosystem service values in estuaries. Ecology and Society 15(4):7. [online] URL: http://www.ecologyandsociety.org/vol15/iss4/art7/

O'Higgins, T., and E. Roth. 2011. Integrating the Common Fisheries Policy and the Marine Strategy for the Baltic: discussion of spatial and temporal scales in the management and adaption to changing climate. Pages 275-294 in G. Schernewski, J. Hofstede, and T. Neumann, editors. Global change and Baltic coastal zones. Springer, Dordrecht, The Netherlands. http://dx. doi.org/10.1007/978-94-007-0400-8_16

Orr, J. C., V. J. Fabry, O. Aumont, L. Bopp, S. C. Doney, R. A. Feely, A. Gnanadesikan, N. Gruber, A. Ishida, F. Joos, R. M. Key, K. Lindsay, E. Maier-Reimer, R. Matear, P. Monfray, A. Mouchet, R. G. Najjar, G.-K. Plattner, K. B. Rodgers, C. L. Sabine, J. L. Sarmiento, R. Schlitzer, R. D. Slater, I. J. Totterdell, M.-F. Weirig, Y. Yamanaka, and A. Yool. 2005. Anthropogenic ocean acidification over the twenty-first century and its impact on calcifying organisms. Nature 437:681-686. http://dx.doi. org/10.1038/nature04095

OSPAR. 2010. Quality status report 2010. OSPAR Commission, London, UK.

Ostrom, E. 2005. Understanding institutional diversity. Princeton University Press, Princeton, New Jersey, USA.

Ostrom, E. 2009. Beyond markets and states: polycentric governance of complex economic systems. The Nobel Prizes 2009. K. Grandin, editor. Nobel Foundation, Stockholm, Sweden.

Österblom, H., A. Gårdmark, L. Bergström, B. Müller-Karulis, C. Folke, M. Lindegren, M. Casini, P. Olsson, R. Dieckmann, T. Blenckner, C. Humborg, and C. Möllmann. 2010. Making the ecosystem approach operational - Can regime shifts in ecological and governance systems facilitate the transition? Marine Policy 34:1290-1299. http://dx.doi.org/10.1016/j.marpol.2010.05.007

Pérez-Ruzafa, A., C. Marcos, C. M. Bernal, V. Quintino, R. Freitas, A. M. Rodrigues, M. García-Sánchez, and I. M. PérezRuzafa. 2012. Cymodocea nodosa vs. Caulerpa prolifera: causes and consequences of a long term history of interaction in macrophyte meadows in the Mar Menor coastal lagoon (Spain, southwestern Mediterranean). Estuarine, Coastal and Shelf Science 110:101-115. http://dx.doi.org/10.1016/j.ecss.2012.04.004

Polonsky, M. J., A. Vocino, S. Landreth Grau, R. Garma, and A. Shahriar Ferdous. 2012. The impact of general and carbonrelated environmental knowledge on attitudes and behaviour of US consumers. Journal of Marketing Management 28:238-263. http://dx.doi.org/10.1080/0267257X.2012.659279

Potts, T., T. O'Higgins, and E. Hastings. 2012. Oceans of opportunity or rough seas? What does the future hold for developments in European marine policy? Philosophical Transactions of the Royal Society A 370:5682-5700. http://dx.doi. org/10.1098/rsta.2012.0394
Rainbow, P. S., S. Kriefman, B. D. Smith, and S. N. Luoma. 2011. Have the bioavailabilities of trace metals to a suite of biomonitors changed over three decades in SW England estuaries historically affected by mining? Science of the Total Environment 409:15891602. http://dx.doi.org/10.1016/j.scitotenv.2011.01.012

Rodhe, J., P. Tett, and F. Wulff. 2006. The Baltic and North seas: a regional review of some important physical-chemical-biological interaction processes. Pages 1033-1075 in A. R. Robinson and K. H. Brink, editors. The Sea, Volume 14B. The global coastal ocean: interdisciplinary regional studies and syntheses: the coasts of Africa, Europe, Middle East, Oceania and Polar regions. Harvard University Press, Cambridge, Massachusetts, USA.

Rosenberg, R. 1985. Eutrophication-the future marine coastal nuisance? Marine Pollution Bulletin 16:227-231. http://dx.doi. org/10.1016/0025-326X(85)90505-3

Savchuk, O. P. 2005. Resolving the Baltic Sea into seven subbasins: $\mathrm{N}$ and $\mathrm{P}$ budgets for 1991-1999. Journal of Marine Systems 56:115. http://dx.doi.org/10.1016/j.jmarsys.2004.08.005

Schiedek, D., B. Sundelin, J. W. Readman, and R. W. Macdonald. 2007. Interactions between climate change and contaminants. Marine Pollution Bulletin 54:1845-1856. http://dx.doi.org/10.1016/ j.marpolbul.2007.09.020

Schlesinger, M. E. and N. Ramankutty. 1994. An oscillation in the global climate system of period 65-70 years. Nature 367:723726. http://dx.doi.org/10.1038/367723a0

Smith, A. 2000. Fitting in with Brussels: implementing the urban waste water treatment directive in England and Wales. Journal of Environmental Policy and Planning 2:115-134. http://dx.doi. org/10.1002/1522-7200(200004/06)2:2<115::AID-JEPP47>3.3.CO;2-2

Söffker, M., K. A. Sloman, and J. M. Hall-Spencer. 2011. In situ observations of fish associated with coral reefs off Ireland. Deep Sea Research Part I: Oceanographic Research Papers 58:818-825. http://dx.doi.org/10.1016/j.dsr.2011.06.002

Stein, E. D., and D. B. Cadien. 2009. Ecosystem response to regulatory and management actions: the southern California experience in long-term monitoring. Marine Pollution Bulletin 59:91-100. http://dx.doi.org/10.1016/j.marpolbul.2009.02.025

Strack, F., and R. Deutsch. 2004. Reflective and impulsive determinants of social behavior. Personality and Social Psychology Review 8:220-247. http://dx.doi.org/10.1207/ s15327957pspr0803 1

Tittensor, D. P., A. R. Baco, J. M. Hall-Spencer, J. C. Orr, and A. D. Rogers. 2010. Seamounts as refugia from ocean acidification for cold-water stony corals. Marine Ecology 31:212-225. http:// dx.doi.org/10.1111/j.1439-0485.2010.00393.x

Tversky, A., and D. Kahneman. 1974. Judgment under uncertainty: heuristics and biases. Science 185:1124-1131. http:// dx.doi.org/10.1126/science. 185.4157 .1124

Wilson, J. C., and M. Elliott. 2009. The habitat-creation potential of offshore wind farms. Wind Energy 12:203-212. http://dx.doi. org/10.1002/we.324 
Appendix 1. Detailed account of the interactions between committed behaviours and GEnS descriptors

Please click here to download file 'appendix1.xlsx'. 